\title{
Developing Community's Sense of Belonging in Building Bahari Community Center (RPTRA) in South Jakarta
}

\author{
Eka Permanasari $^{1}$, Sahid $^{1}$, Rahma Purisari ${ }^{1}$ \\ ${ }^{1}$ Department of Architecture, Universitas Pembangunan Jaya, Jalan Cendrawasih Raya B7/P, Tangerang \\ Selatan, Banten, Indonesia \\ eka.permanasari@upj.ac.id
}

\begin{abstract}
The capital city is full of layered memories from the authority in representing power and identity and from the everyday uses of place. Public space often represents and legitimates power. The purpose of the top-down approach in design is imminent, and authority uses architecture and urban design as their means of showing identity. However, an excellent urban design approach should include public participation in the process, allowing the users to take in charge and contribute to decision making. A good-city should be designed based on a common good for all. The bottom-up approach uses the participative design method to allow the citizen to speak, be heard, and take in charge. It ensures sustainable activity as a community would be involved in using the place and preserving the resources. Everyone contributes to the city as citizen members of the political community. As a result, the community would have a sense of belonging and engagement towards the public space. This research documented and analysis this participative design approach during the development of the Jakarta community center (RPTRA) in South Gandaria. As one of the pilot projects, the Bahari community center was one of the successful projects that included community participation during the design and implementation process. Through observation, interview, and series of discussions, authors were engaged in this action research of implementing a bottom-up approach in designing public space.
\end{abstract}

(C) 2019 IJBESR. All rights reserved.

Keywords: Community Center, Sense Of Belonging, RPTRA

\section{Introduction}

Kelurahan Gandaria Selatan (South Gandaria district) is one of the densest areas in South Jakarta, with a population density of 14,212 people per sqm [1]. Although the South Jakarta area is famous for the wealthy, the social gap is very striking. It is easy to find the contrast phenomena where behind the luxury residential wall enclave lays the densely populated slum settlements. These slums area was notorious for lacking public spaces which are very crucial in developing a good and healthy environment.

Apart from the lack of public places, slum and highly dense areas are easy targets for fire and flood. One burning house can quickly spread to others. During the rainy season, these slums are also often being flooded for days. The main problem of these settlements is that there is no evacuation site for both events. Therefore, once the event occurs, some take places such as mosques and roadsides as their temporary shelter. The absence of an integrated public space capable of helping the community to cope with this seasonal problem has an impact on society at large. The density of settlements and the unavailability of shelters, communal kitchen, sanitation, and health facilities make residents and children vulnerable to diseases. Another problem is the fact that some existing public places belonging to the government have been illegally used as parking lots or occupied by street vendors. Other public spaces are turning the function of being a place for selling and gathering community groups from specific communities. 
Based on these concerns, in 2014, the Family Welfare Organization (PKK) led by Veronika Ahok from the Provincial Team of DKI Jakarta planned to create an integrated Community Center that can accommodate community activities from all walks of life. To provide a childfriendly city, PKK focused on delivering public facilities that support the development of children. For them, children are seen as vulnerable and need protection, a safe place to do everyday activities such as going to school, playing, and having recreation. This right also applies to those who live in slums and dense settlements. Generally, these dense settlements are less healthy due to lack of public services such as clean water facilities, sanitation, and proper garbage disposal.

Initially, the program is implemented using a top-down approach and is expected to solve the problems identified in South Gandaria. However, this approach is seen as unsustainable because of the lack of community involvement in development [2]. The lack of ownership and a sense of belonging towards the public place is very common. Most of the public places will be abandoned not long after they had been launched. Based on this concern, Jakarta's government cooperates with Family Welfare Organization, Sociologists, Architects, and Urban Designers to include the society in the process of development and management of RPTRA in South Gandaria [3].

By combining the top-down and bottomup approaches in building the public place, it will form a sustainable design. This process allows the interests of the government and the community's hope to meet and prioritize common interests. A public place is owned by the government, but in terms of the daily uses, it depends on the community. Therefore, these two stakeholders should have dialogue in making public space. This method, which will later be applied to various public space design, is called as Participative Design Method. Therefore, this research focuses on the process of community involvement in designing, constructing, and managing public spaces so that participative design methods can be the models in public placemaking.

This paper focused on the development of public places, which allows the community as a stakeholder and part of policymakers. If we examine the literature on urban development from the point of view of policy (government), most of the public places are built to convey the success and power of a particular regime [4] [5] [6]. These urban forms are focusing on physical development and often overlook their everyday uses. A community certainly has specific characteristics that characterize an urban society. The way people use the public place might be different from the way it was intended [7] [8] [9]. Therefore, the design of public places should accommodate the needs and character of the community [10].

People's expectation is heavily relied on in this design process. To know what they are, key information such as what people say, do, feel, and dream of public space should be explored. The process of design participation needs to know the difference between what the client wants and who the design is meant to be. The general public should be in an inclusive state throughout the architectural process. Participation holds a vital role in this method of design as an architectural practice should be more engaged and relevant to the everyday world.

To understand the level of citizen participation in the design, we can analyze through Arnstein's Ladder of Citizen Participation [11]. Arnstein identifies three levels of involvement (non-participation, tokenism, and citizen-power). The first 
level (non-participation) covers manipulation and therapy. The next level (tokenism) includes informing, consultation, and placation. While the highest level of participation (citizen power) covers partnership, delegated authority, and Citizen control [11]. In the non-participation level, the government sees that the citizens need to be educated and cured. In tokenism, the citizen's voice is heard, but the authorities do not automatically implement the idea. In degrees of citizen power, the citizens have the full right to decide policies. To ensure public participation in the participative design approach, we implement degrees of tokenism.

\section{Methodology}

To obtain a participative design model in the construction of the Child-Friendly Integrated Public Space (RPTRA), the approach used in Qualitative Methodology. The nature of the participative design research is to observe and look for the community's perception and sense of belonging. The sense of ownership was investigated through the following methods: a) Literature Study, b) Surveys, c) In-depth Interviews and d) Observation.

\section{Result and Discussion}

This research aimed to see the public space design method that prioritizes the dialogue between power (government) and its citizens. Thus, the participative design approach that empowers the citizen in making public policy becomes essential. Also, this approach can be used as a policy prototype to be applied to all public placemaking. There are three steps conducted throughout the participative design process (social mapping, initial design, and final design).

\subsection{Social Mapping}

The participative process begins with a social mapping of the area to finds out the needs of the community, which need to be fulfilled in RPTRA Bahari. The mapping activity was carried out by discussing with the community representatives and continued with observations and in-depth interviews with the community around RPTRA. The mapping result showed that around the area of RPTRA, many planned activities had been ongoing. The activities such as the community's reading park, angklung, playground, children's learning forums, computer education program, English courses, Gerakan Sayang Ibu, childfriendly city activities, children's reading houses, sports (futsal, gymnastics, badminton, volleyball) arts (dance, acoustic bands), social activities, recitation, leadership training (organization, teamwork, and public speaking), [Figure 1, 2, 3]. The activity was consistent, and the community actively engaged with the events.

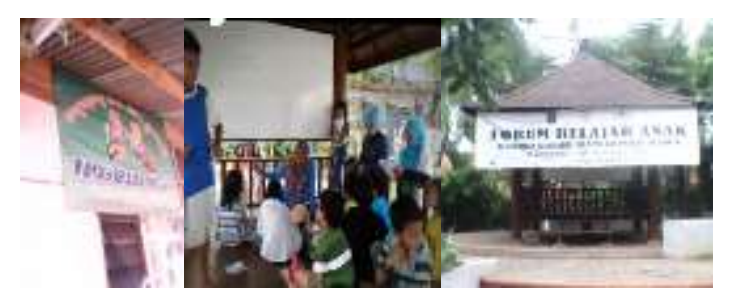

Figure 1. Floor Plan of RPTRA Source: Author, 2015

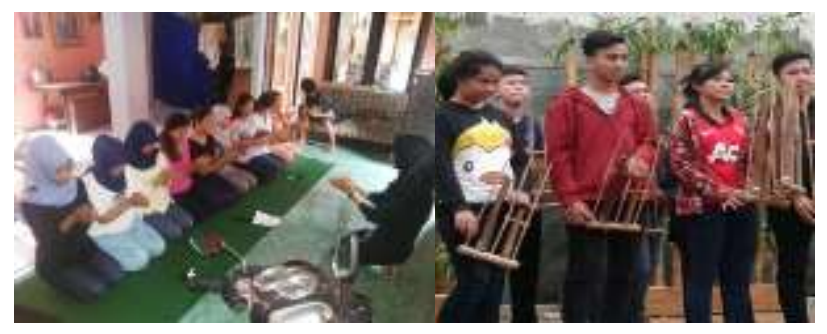

Figure 2 : Angklung Community and Traditional Saman Dance

Source: Author, 2015 
In addition to these activities, there were also creative economic activities which include:

Culinary activities: making Coconut cookies, Rengginang, dried potatoes, Bandeng Presto, Bugis Cake, Asinan Betawi, Pepe Cake, Selendang Mayang Ice, Soy Milk, and Pletok beer.

Handicraft activities by the UP2K group, including recycled patchwork, crafts, banknotes crafts, as well as Gandaria Betawi batik cloth.

Apart from these daily activities, the community in Gandaria Selatan also involved in environmental movement such as:

- Abuserin Waste Bank (BSA) located in RW 06 and RW 07 is managed by Karang Taruna [Figure 3].

- The flood disaster response activity in RW 07 is at Tagana post

The PRIMA Women's Development Cooperation (KPWS PRIMA) established in 2001 [Figure 4]

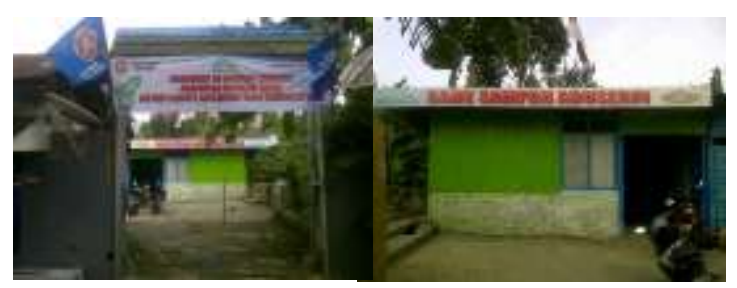

Figure 3. Abuserin Waste Bank (BSA) in South Gandaria

Source: Author, 2015

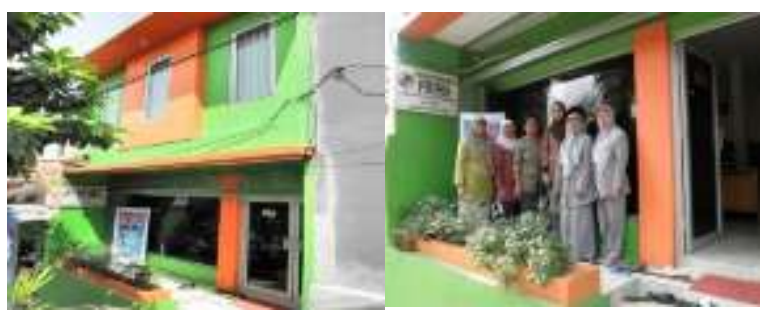

Figure 4. The PRIMA Women's Development Cooperation (KPWS PRIMA) Source: Author, 2015

The participative process was also carried out by holding FGDs as a medium for citizens to distribute their aspirations for the public space and build their understanding and participation of citizens to develop the region through the RPTRA. The first FGD was held on January 16th, 2015 [figure 5]. The participants understood that children are essential assets that need to be considered by all members of the community. Therefore, it is essential to provide them adequate space to play. Children will learn to recognize themselves, know other people, interact with others as well as build their intelligence.

Everyone contributes to the city in defining the common good. When everyone has the right to the city, their right is also defined by other's right [12]. As Jan Gehl puts it, being among others, seeing and hearing others, receiving impulses of others can give positive experiences [13]. Unfortunately, public places do not often reflect a safe environment. Children need to be protected from a variety of negative influences such as physical, sexual, emotional abuse, child trafficking, child exploitation, drugs, and cigarette addiction. They need to grow in a positive environment to become better human beings. One way to achieve this desire is to create a public place where citizens can gather regularly, interact with one another. The massively dense population should not hinder the community from having a better quality of life.

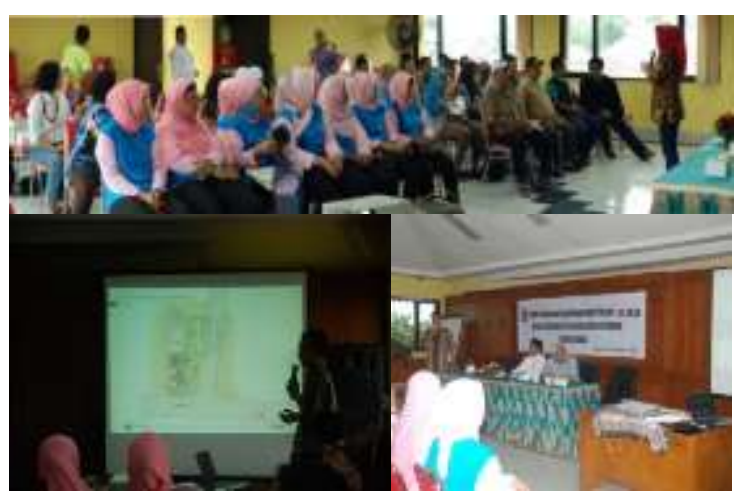


Figure 5. Focus Group Discussion 1: RPTRA by Mr. Imam Prasodjo and Preliminary Design by Mr. Noerzaman Source: Author, 2015

\subsection{Initial Design Proposal}

Achmad Noerzaman, as the architect, proposed the initial design of the RPTRA by processing the existing field that covers an area of 926 sqm and a building area of $207 \mathrm{sqm}$. The open space in the RPTRA is flexibly designed to be used as a means to play badminton while accommodating social activities such as communal Quran reading, social gathering, rotating saving clubs, and at the same time works as a place of evacuation during the flood season. The available building is planned to be used as a multipurpose building that accommodates early childhood education programs (PAUD) activities, Posyandu, PKK, youth activities, children's libraries, children's parks, and sports. [Figures 6 and 7].

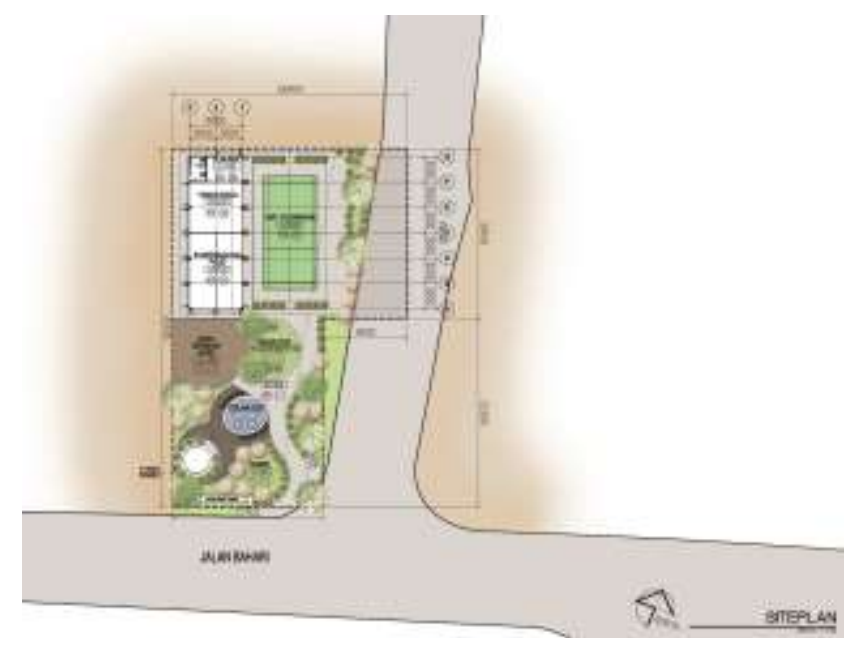

Figure 6. Proposed Site Plan of RPTRA Bahari, South Gandaria

Source: PT Arkonin, 2015
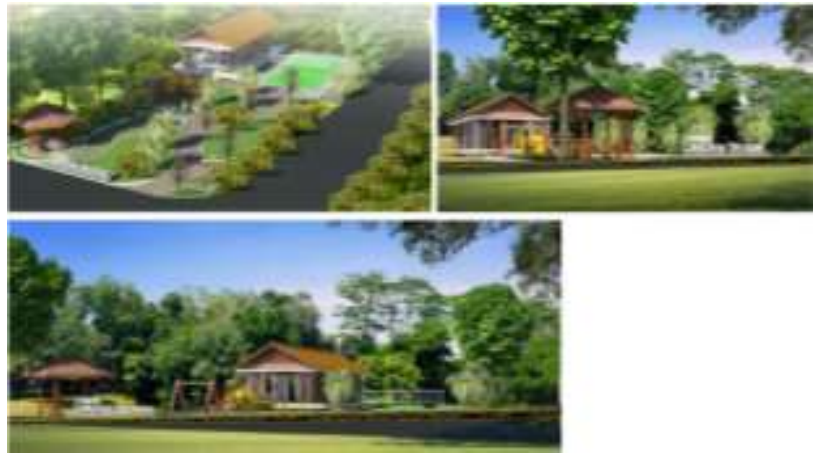

Figure 7. Proposed Design of RPTRA Bahari, South Gandaria Source: PT Arkonin, 2015

\subsection{Final Design Proposal}

The process of including public participation was heavily imolemented. The architect presented the design and received several feedbacks from the community. After going through several FGDs, PT Pembangunan Jaya conveyed the final results of the planning which accommodated the various comments and suggestions of the community [figure 8,9 and 10]:

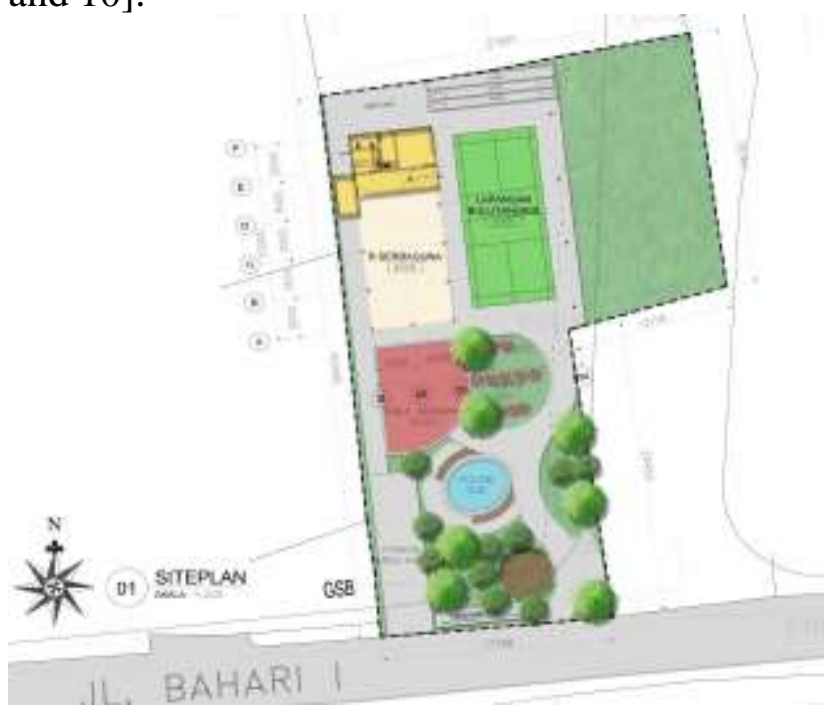

Figure 8. Site Plan Revision after FGD Source: PT Arkonin, 2015 


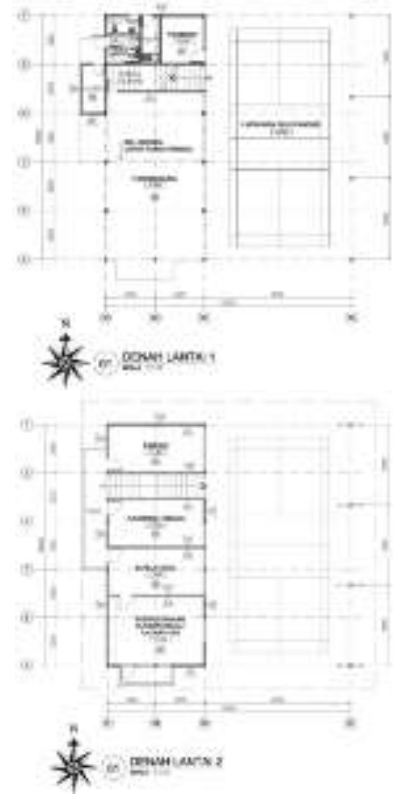

Figure 9. 1st Floor and 2nd Floor Plan after FGD Source: PT Arkonin, 2015

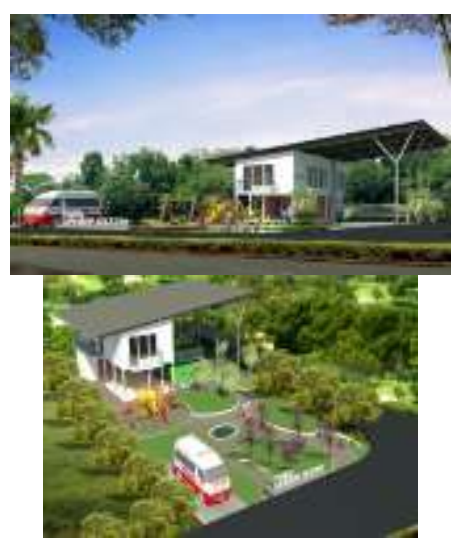

Figure 10 : RPTRA Design after FGD Source: PT Arkonin, 2015

The participative approach through FGD was not only aimed to build an understanding and togetherness when formulating the needs and design of RPTRA but also to formulate the activities that will be carried out in RPTRA Bahari, South Gandaria. The following are the efforts of the citizens to map out the activities they have planned. From their plan, which activities they would like to continue to do in RPTRA will be built later, and new activities they want to do in the future.

The results of mapping activities based on age groups:
1. Children

a. Existing Activities

- Posyandu Balita

- BKB Paud

- Mandatory study hours (19.00 21.00)

- Playing in the garden

- Free learning forum

- Marawis and hadrah

b. Dormant activities to be activated

c. Desired Activities

- BKB Paud with a collection of activities

- Children day care

- Tools for children to play, suitable for their age

- Posyandu which is integrated with the PMT

- Secretariat for Children's Forum

- Audio visual room for children

2. Youths

a. Existing Activities

- Art (Hadrah, Marawis, Saman, Angklung)

- Sport (Futsal)

- Religious (Prayers, Important Days, Takbir)

b. Dormant activities to be activated

- Sports (badminton, morning exercises, taekwondo, silat)

- Art (Band, Choir, Drama)

c. Desired Activities

- Health (Mass circumcision, free treatment)

- Social (social services, culture festivals, nature meditation)

- Art (performing arts, music festival)

3. Mothers

a. Existing Activities

- Information center and Counselling for Family

- Guide for craft and skills (UP2K)

- Reciting prayers

- Art (angklung, marawis)

- Sports (Heart exercises, aerobics) 
- Health (posyandu, posbindu, jumantik)

b. Dormant activities to be activated

- Courses in culinary and fashion

c. Desired Activities

- Family consultation room

- Necessary Sport facilities

- Courses and trainings

- Catering service with complete facilities

- Canteen

- Training room (Arts and crafts)

4. Fathers

a. Existing Activities

- Rukun Kematian

- Monthly gathering

- Routine prayers

- Reminders of Big Days

- Monthly meetings

- Health exercises

b. Dormant activities to be activated

c. Desired Activities

5. Elderly

a. Existing Activities

- Prayers

- Family development for the elderly

b. Dormant activities to be activated

- Exercises for the elderly

- Elder forum

- Family development for the elderly

- Posyandu for elders

- Counselling for elders

c. Desired Activities

- Health room for the elderly

- Stone therapy

- Elderly exercises

- Elder forum

Mapping of Activities based on the 10 Main Programs of the PKK

1. Appreciation \& Practice of Pancasila

Proposed Activities: Hadroh, Marawis, Traditional Dance, Band, Choir, Taekwondo, Pencaksilat, Cultural
Festival, Tournament between RW, socialization about Children

2. Mass Cooperation

Proposed Activities: Reminder of Islam's Big Days, Elder Forum, Community service, Mass circumcision, Social service, National Children's Day

3. Food

Proposed Activities: Nutritional pool, Nutritional garden

4. Clothing

Proposed Activities: Sewing courses

5. Housing \& Governance of Household

6. Education and Skill

Proposed Activities: Children's

Learning Forum, Loving to read, capacity building, BKB-PAUD, Training for recycling skill, Indoor library, Counselling by BKB, Counselling by BKR, Counselling by BKL, Information center and family counselling, TOGA Training, PTP, KWT, Business management training, Dasawisma training.

7. Health

Propose Activities: Heart exercises/aerobics, Posbindu (Post for non-contagious diseases), Socialization of

PTM, Elderly exercises, Posyandu (Integrated service post), Socialization about health, Free treatment, Accommodation for chess.

8. Development for Living in Cooperation Proposed Activities: UP2K training, PKK Materials, Socialization.

9. Sustainability of the Environment Proposed Activities: Waste management, Greening program.

10. Health Planning

Proposed Activities: PPKS (Center for prosperous family living).

Based on the listed activities and PICs, we could confirm that this public space will be used accordingly and never been abandoned. All elements from the community are involved and submissively participate in the activities. 


\section{Conclusion}

Based on the three steps of participative design processes, citizens were eager to be involved and actively engaged in the design of RPTRA. By involving all citizens in determining the needs, design, and activities carried out in RPTRA Bahari, South Gandaria, through the FGD proved to be an effective way to foster a sense of belonging of the community towards the RPTRA. This FGD activity became the key to the participative design approach. This approach will bring all local apparatus, and its citizens cooperative synergistically, and communicatively. Through this process, citizens are no longer seen as the object of the development, but rather the subject of the development. This process becomes the new urban approach in designing public space.

This paper suggests that in terms of designing public space, architects and urban designers need to think about the social dimension into the design. The design should be clearly specified for who and how it is going to be used in the future. Also, the government should think about the sustainability of the project in terms of social capital. Instead of making the physical structure, social cohesion, and community participation are needed to ensure the public place is for public use.

\section{Acknowledgements}

This research was part of CompetencyBased Research funded by Ministries of Research, Technology, and Higher Education Grant in 2017/2018, Republic of Indonesia. We would like to show our gratitude to the Provincial Team of DKI Jakarta Plans and Pembangunan Jaya Group for the opportunity to cooperate in conducting the RPTRA pilot project. We are also immensely grateful to RPTRA South Gandaria officers who facilitated us during this research.

\section{References}

[1] Statistik, B. P. Statistik Daerah Kecamatan Cilandak. Jakarta: BPS Kota Administrasi Jakarta Selatan; 2015.

[2] Jones, P., Petrescu, D., \& Till, J. Architecture and Participation. London and New York: Routledge; 2012.

[3] Elyda, C., \& Budiari, I. Jakartans Enthused with New RPTRA Community Centers. The Jakarta Post; September 2017.

[4] Anderson, B. Imagined Communities: Reflections on the Origin and Spread of Nationalism. London: Verse; 1991.

[5] Alsayyad, N. Forms of Dominance: On the Architecture and Urbanism of the Colonial Enterprise. Avebury: Aldershot; 1992.

[6] Cowen, M., \& Shenton, R. Doctrines of Development. London: Routledge; 1996.

[7] De Certeau, M. Walking in the City. In S. During (Ed.), The Cultural Study Reader. London and New York: Routledge; 1993.

[8] Lefebvre, H. Writing on Cities. Oxford: Blackwell Publisher; 1996.

[9] Simmel, G. Sociology: Inquiries into the Construction of Social Forms. (translated by Blasi, A \& Jacobs, A). USA: Brill; 2009.

[10] Montgomery, C. Happy City. London: Penguin Books; 2013.

[11] Arnstein, S. R. A Ladder of Citizen Participation. Journal of the American Planning association, 35(4); 1969, p. 216-224.

[12] Friedman, J The good City: In defence of Utopian Thinking. In the Prospect Cities. Minneapolis: University of Minnesota Press. 2002. p.103-116.

[13] Gehl, J. Life Between Buildings: using public space. Translated by J.Koch. 2011. 